\title{
Differential Expression of Chemokines, Chemokine Receptors and Proteinases by Foreign Body Giant Cells (FBGCs) and Osteoclasts
}

Usman A. Khan'1 , Saeed M. Hashimi², Mahmoud M. Bakr², Shareen H. Elshiyab², Mark R. Forward $^{1}$, Nigel A. Morrison ${ }^{1}$

${ }^{1}$ School of Medical Science, Griffith University

${ }^{2}$ School of Dentistry and Oral Health, Griffith University

\section{Overview}

Osteoclasts are derived from the fusion of monocyte / macrophage lineage and are responsible for bone homeostasis ${ }^{1}$. Macrophages in the presence of a foreign body can also fuse to form Foreign body giant cells ${ }^{2}$. One of the important chemotactic factor for macrophages is $\mathrm{CCL} 2^{3}$, that binds to its primary receptor $\mathrm{CCR} 2^{4}$. Here we test the differential expression of chemokines, their receptors and proteinases by these cells to identify potential and specific targets.

\section{Materials and Methods}

Osoteoclasts and FBGC were cultured from the bone marrow cells were divided into two groups. One group of cultures were fixed and subsequently TRAP stained while the second group was used for gene expresssioin analysis.

\section{Results}

A
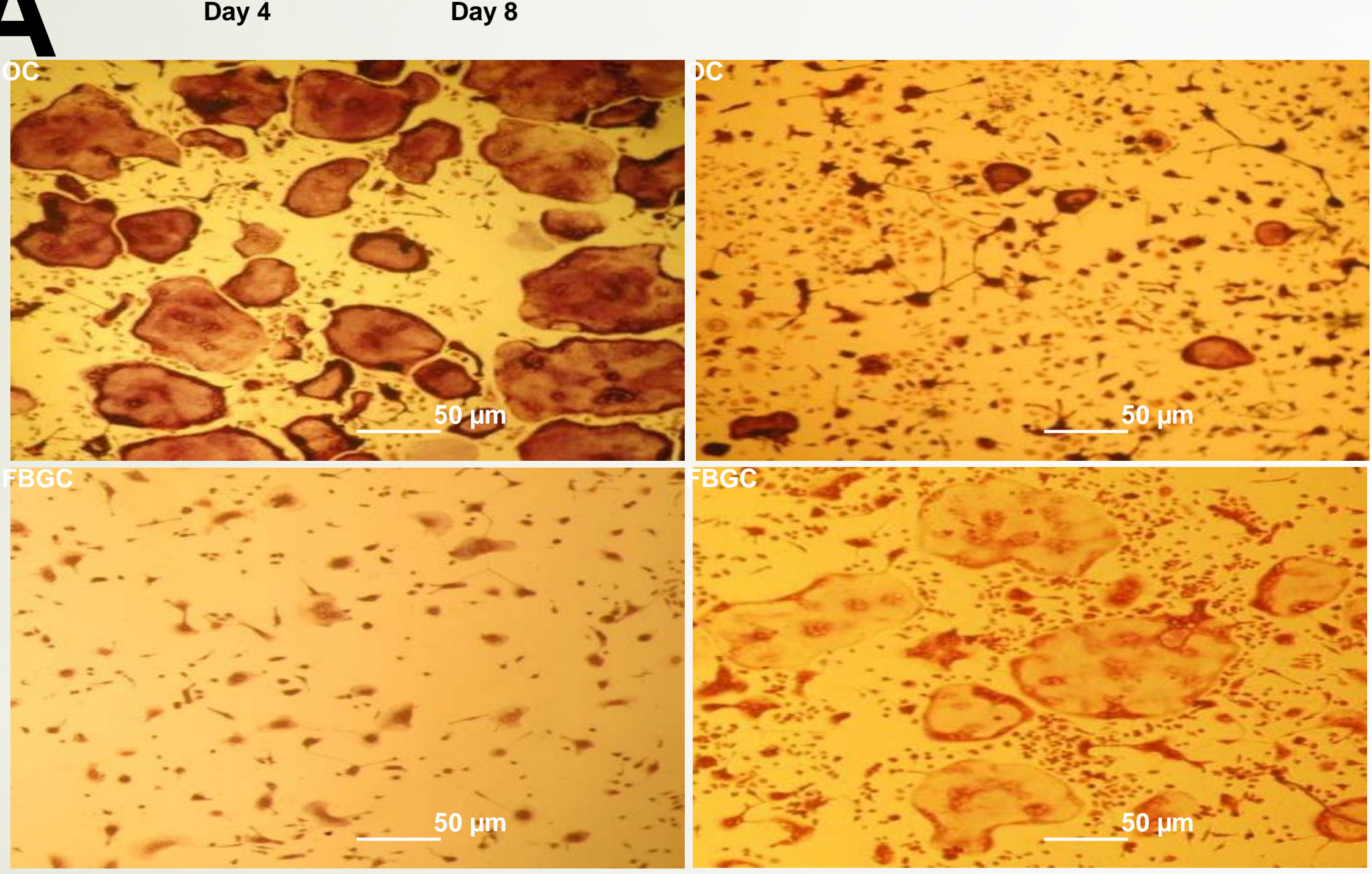

B

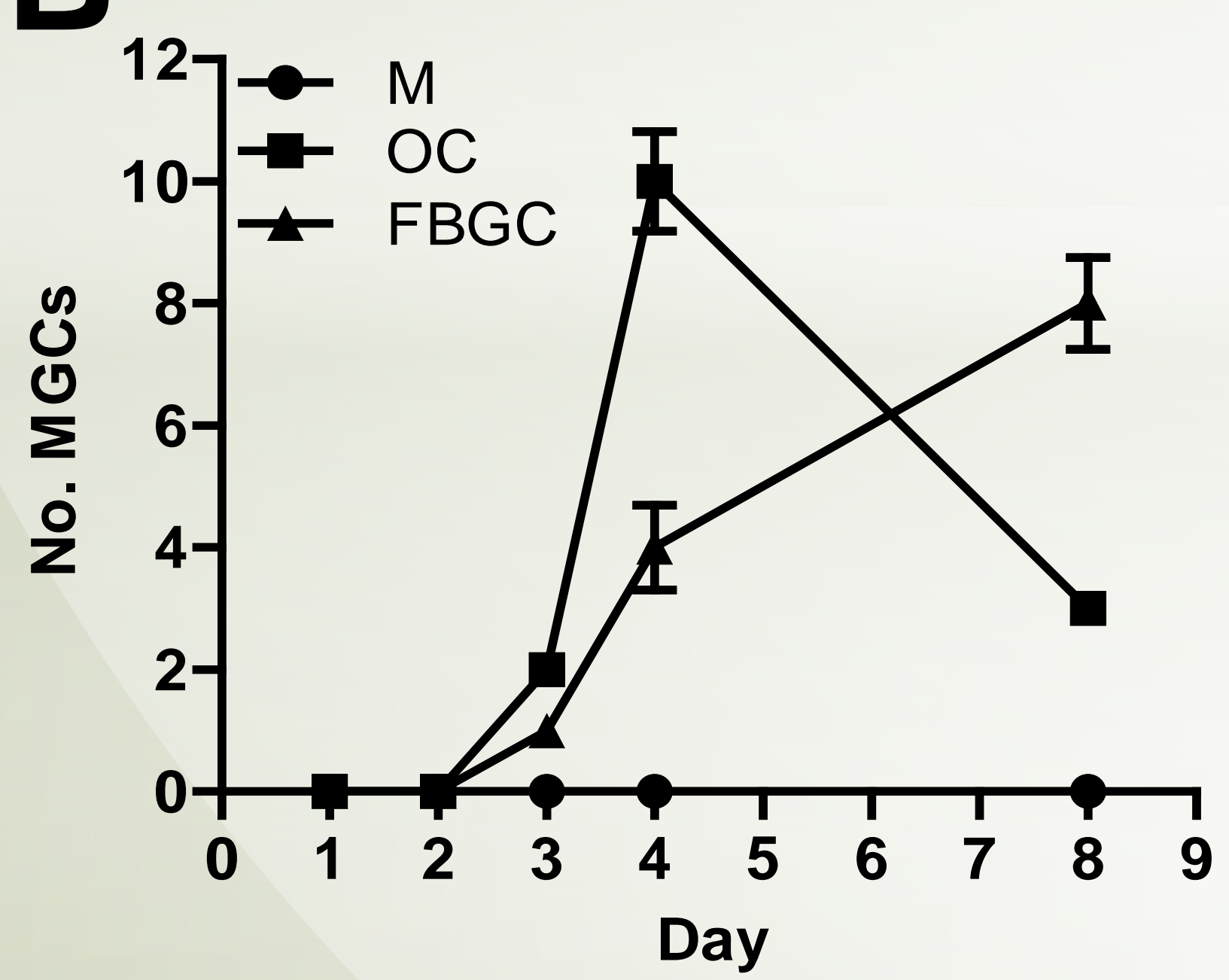

Fig. 1 Osteoclasts numbers and size were significantly more on lday 4 compared to FBGCs while on day 8 FBGCs were recorded in greater number compared to osteoclasts
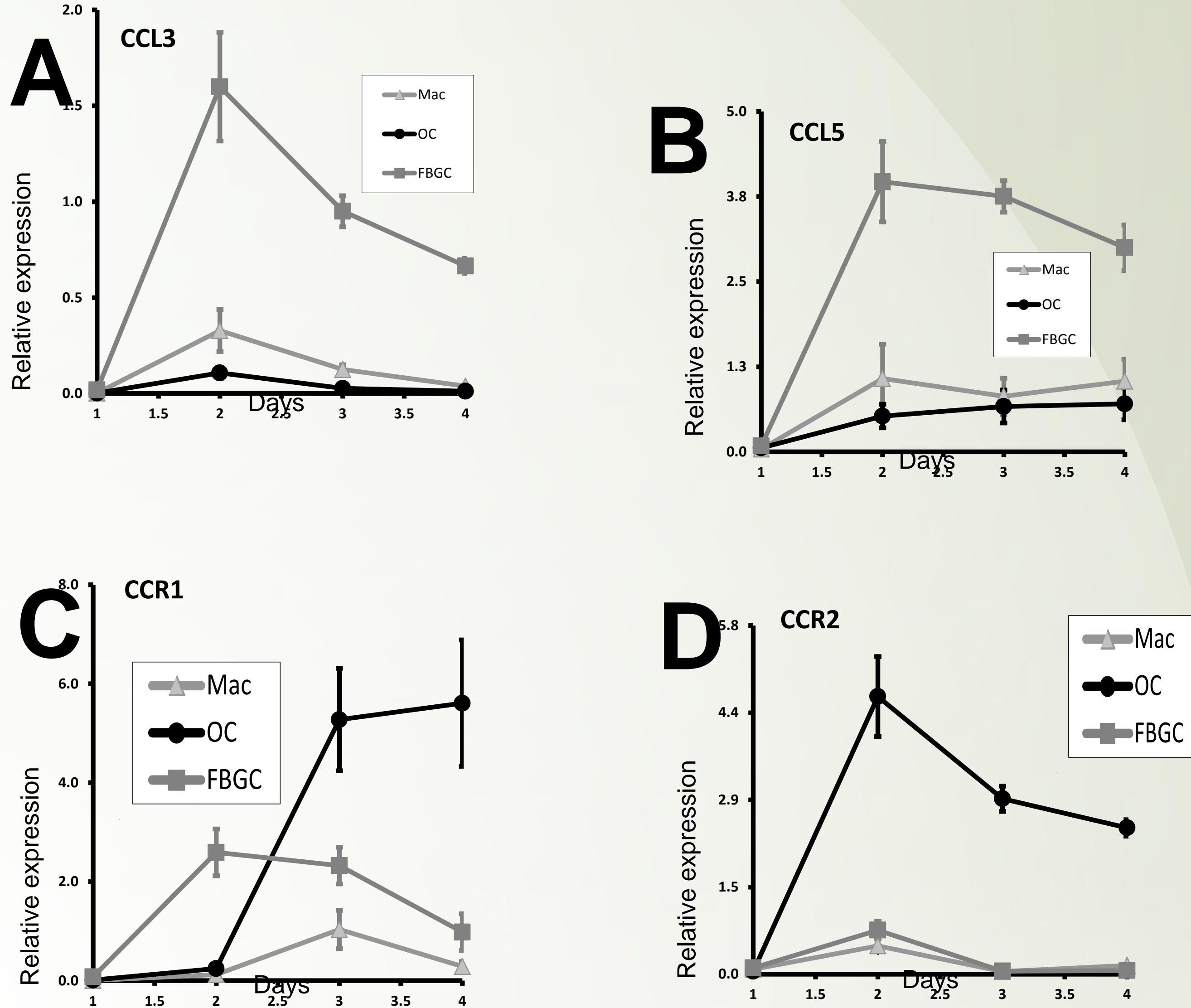

Fig. 2 Chemokines and their receptor expression by osteoclasts and foreign body giant cells

\section{Discussion}

FBGCs are associated with inflammatory conditions (i.e. foreign body reactions) hence the inflammatory chemokines were more expressed by these cells compared to osteoclasts. Intrestingly, the expression of chemokine receptors were highly expressed by osteoclasts compared to FBGCs.

Furthermore, FBGCs exibited a significantly lower expression of osteoclast related genes (i.e.RANK, NFATc1, MMP9 TRAP etc) and were not able to resorb bone,

\section{References}

1. Brodbeck WG, Anderson JM. Giant cell formation and function. Curr Opin Hematol. 2009 Jan;16(1):53-7.

2. Horsley $\mathrm{V}$, Pavlath $\mathrm{G}$. Forming a multinucleated cell: molecules that regulate myoblast fusion. Cells Tissues Organs. 2004;176(1-3):67-78

3. Miyamoto T. Regulators of osteoclast differentiation and cell-cell fusion. Keio J Med 2011;60(4):101-5

4. Binder NB, Niederreiter B, Hoffmann O, Stange R, Pap T, Stulnig TM, et al. Estrogen-dependent and $\mathrm{C}-\mathrm{C}$ chemokine receptor-2-dependent pathways determine osteoclast behavior in osteoporosis. Nat Med. 2009 Apr;15(4):417-24 